\title{
FIRST RECORD OF JAGUAR (PANTHERA ONCA) FROM THE STATE OF HIDALGO, MÉXICO
}

\author{
Melany Aguilar-López¹,3, Josefina Ramos-Frías ${ }^{1}$, Alberto E. Rojas-Martínez \\ and Cristian Cornejo-Latorre ${ }^{2}$
}

\begin{abstract}
We documented the first record of jaguar (Panthera onca) in the state of Hidalgo, México. With this record, the gap in the distribution of jaguar between San Luis Potosí and northwestern Puebla is reduced. In July 2013, we found 2 tracks on a trail in a pine-oak forest, and in October, we photographed a jaguar in an oak forest. Both sites are located within the Parque Nacional Los Mármoles in Sierra Gorda of Hidalgo. These records represent the first evidence of the presence of jaguar in Hidalgo, which is among the few states where all 6 species of felids that inhabit México occur.
\end{abstract}

Resumen.-Documentamos el primer registro de jaguar (Panthera onca) en el estado de Hidalgo, México. Este registro sugiere la continuidad en la distribución del jaguar entre San Luis Potosí y el noroeste de Puebla. En julio de 2013 encontramos dos huellas de jaguar sobre un sendero en un bosque de pino-encino y en octubre del mismo año fotografiamos un jaguar en un bosque de encino; ambos sitios se localizan dentro del Parque Nacional Los Mármoles, en la Sierra Gorda Hidalguense. Estos registros representan la primera evidencia de la presencia de jaguar para Hidalgo, con lo cual se incluye entre las pocas entidades que albergan a las seis especies de felinos que viven en México.

The jaguar (Panthera onca) is the largest felid in the Americas (Seymour 1989) and one of the most threatened carnivores in México (Ceballos et al. 2007). The jaguar is tolerant of a variety of environmental conditions; nevertheless, its distribution is mainly associated with tropical and subtropical environments at lower altitudes (from sea level to 1200 masl), where its abundance is related to available prey, water, and dense vegetative cover (Tewes and Schmidly 1987, Aranda 1996, Sunquist and Sunquist 2002, Rodriguez-Soto et al. 2011). However, other studies have reported the presence of jaguar in temperate environments (pine-oak habitats) at altitudes 1800 masl (Brown and López-González 2001, MonroyVilchis et al. 2009).

In the past, the geographic range of the jaguar extended from the southwestern United States to southern Argentina (Seymour 1989). Since the mid-1900s, this species has been extirpated from large portions of its original distribution, losing nearly $54 \%$ of its geographic range with high levels of habitat fragmentation (Nowell and Jackson 1996, Sanderson et al. 2002). However, $78 \%$ of the jaguar's historical range still potentially allows movement through the landscape (Rabinowitz and Zeller 2010). In México, approximately 312,318 $\mathrm{km}^{2}$ (about $16 \%$ of the total jaguar distribution) is considered highly suitable habitat for jaguar. The area includes mainly coastal areas from Tamaulipas and Sonora to Yucatan and Chiapas, the Balsas River basin, Soconusco, and the Sierra Madre Oriental (Rodriguez-Soto et al. 2011).

Jaguars face many problems that threaten population viability, such as poaching, illegal trade, loss and fragmentation of habitat, as well as competition with humans for prey (Medellín et al. 2002, Sanderson et al. 2002, Chávez et al. 2005, Ruíz et al. 2006). Jaguar persistence is linked to landscape configuration, and fragmentation is more detrimental to the species' long-term viability than habitat loss (Zanin et al. 2015). Therefore, this species is listed as near threatened on the International Union for Conservation of Nature Red List of Threatened Species (Caso et al. 2008) and in México is classified as an endangered species (Secretaría del Medio Ambiente y Recursos Naturales 2010).

${ }^{1}$ Centro de Investigaciones Biológicas, Universidad Autónoma del Estado de Hidalgo, Carretera Pachuca-Tulancingo km 4.5 s/n, Ciudad Universitaria, C.P. 42184. Mineral de la Reforma, Hidalgo.

${ }^{2}$ Centro de Investigaciones Biológicas del Noroeste, Instituto Politécnico Nacional 195, Colonia Playa Palo de Santa Rita Sur, La Paz, Baja California Sur 23096, México.

${ }^{3}$ Corresponding author. E-mail: mel1983aguilar@hotmail.com 


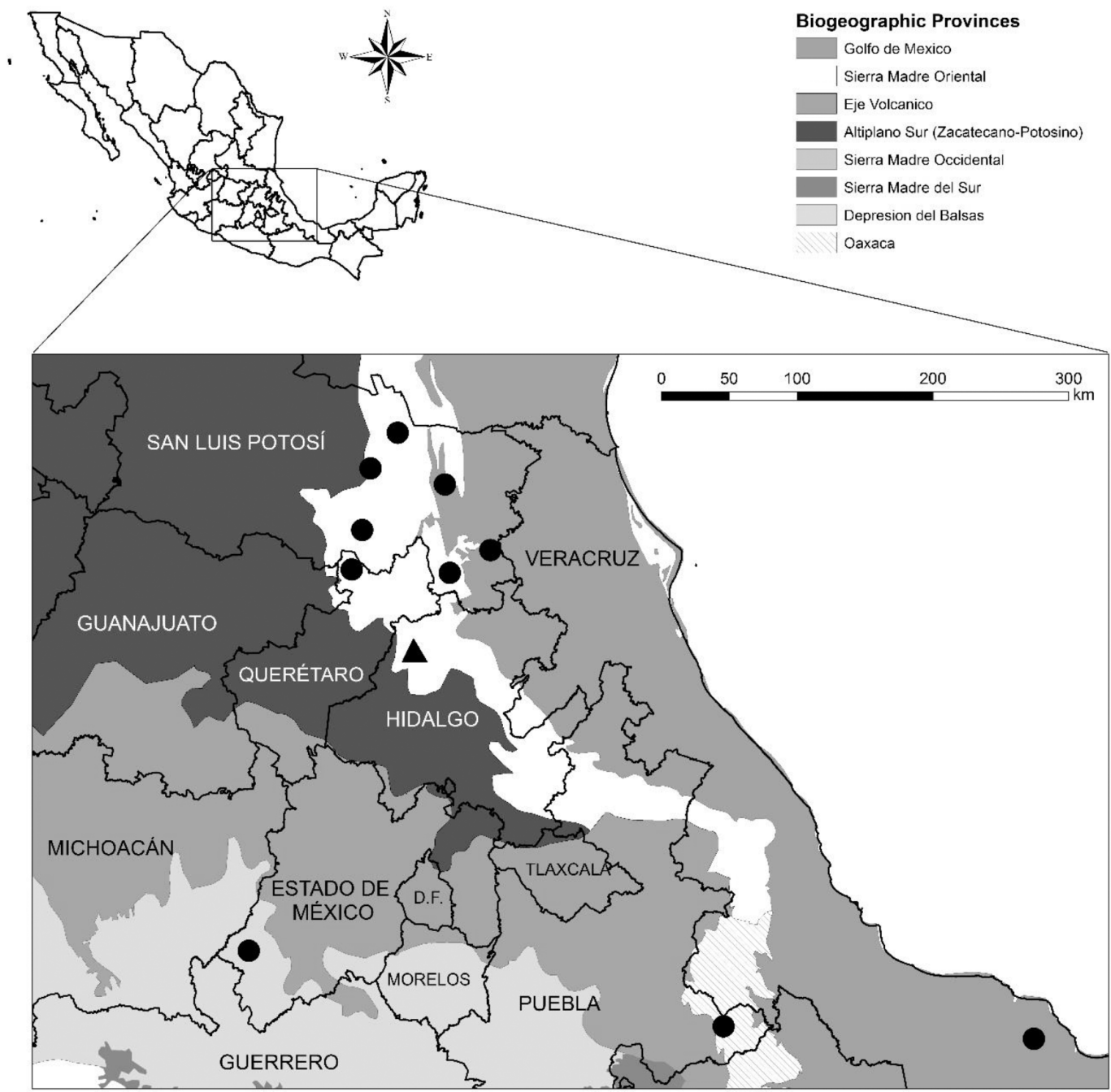

Fig. 1. New records of the jaguar (Panthera onca) from the state of Hidalgo in the Sierra Madre Oriental (triangle), and published adjacent records in central México (solid circles) from the states of Querétaro (Telléz-Girón and LópezForment 1995, Ortega-Urrieta 2005), Estado de México (Monroy-Vilchis et al. 2008), Puebla (Villareal et al. 2005), San Luis Potosí (Rosas-Rosas and López-Soto 2002, Villordo-Galván et al. 2010), and Veracruz (Coates-Estrada and Estrada 1986). The biogeographic regions are indicated (Comisión Nacional para el Conocimiento y Uso de la Biodiversidad 1997).

In central México, there is great interest in knowing the actual distribution and status of jaguar populations so that effective conservation strategies can be implemented for this species (Rodríguez-Soto et al. 2011, 2013). Thus, it is necessary to have reliable records and updated information about distribution of jaguar. Although the state of Hidalgo is located within the potential distribution of jaguar (Rodriguez-Soto et al. 2011), there are no records that confirm its presence in the state (Mejenes-López et al. 2010). The closest records are from adjacent states (Fig. 1): Querétaro (Telléz-Girón and López-Forment 1995, Ortega-Urrieta 2005, Ramírez-Bravo 2007), Estado de México (Monroy-Vilchis et al. 2008), Puebla (Villareal et al. 2005), San Luis Potosí (Rosas-Rosas and López-Soto 2002, Villordo-Galván et al. 2010), and Veracruz (Coates-Estrada and Estrada 1986).

Our study was conducted in the Parque Nacional Los Mármoles (PNLM), a natural 

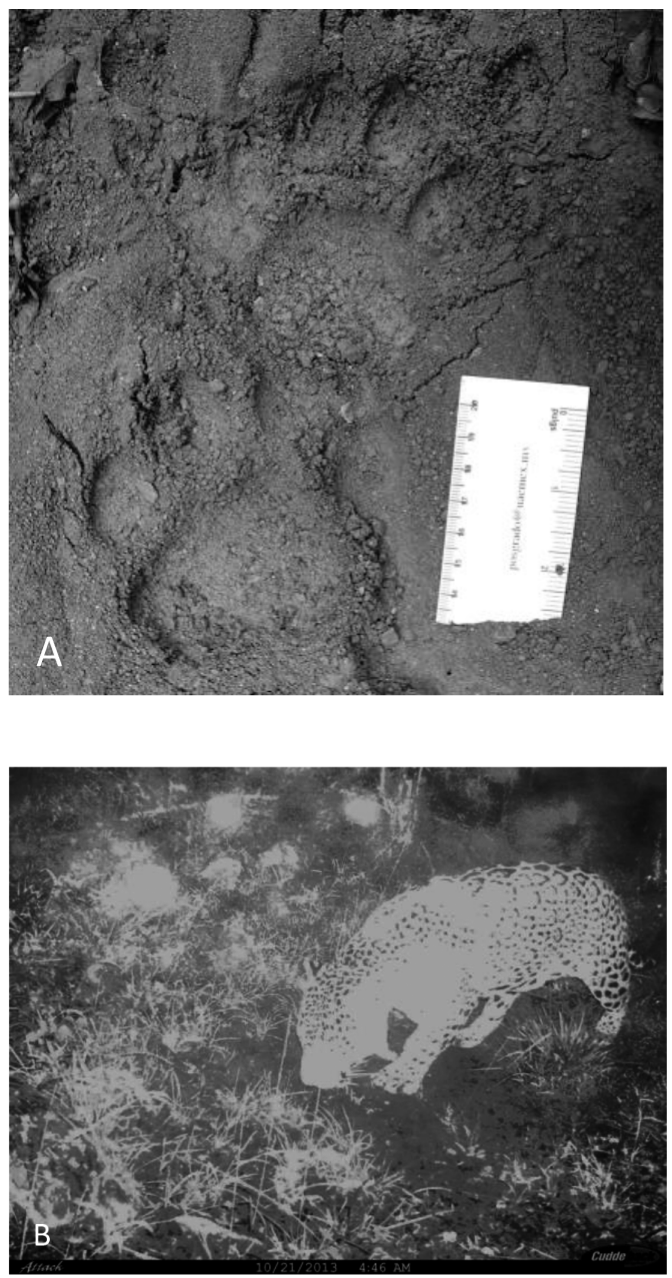

Fig. 2. Records of jaguar (Panthera onca) from Pacula, within the Parque Nacional Los Marmoles, Hidalgo, Mexico: A, track of an adult male; B, photograph of an adult.

protected area of $230 \mathrm{~km}^{2}$ in northwestern Hidalgo within the Sierra Madre Oriental. The area is located at $20^{\circ} 45^{\prime} 39^{\prime \prime}-20^{\circ} 58^{\prime} 22^{\prime \prime} \mathrm{N}$, $99^{\circ} 08^{\prime} 57^{\prime \prime}-99^{\circ} 18^{\prime} 39^{\prime \prime} \mathrm{W}$ at $1500-2820$ masl, in the Sierra Gorda of Hidalgo. It includes part of the territories of the municipalities of Jacala de Ledezma, Nicolas Flores, Pacula, and Zimapán (Comisión Nacional de Áreas Naturales Protegidas 2007). The dominant vegetation type in the Parque Nacional Los Mármoles is mixed pine-oak forests, and the most common tree species include Quercus affinis, Quercus laeta, Quercus mexicana, Pinus cembroides, and Juniperus deppeana (Secretaría de Agricultura y Recursos Hidráulicos 1994,
Velázquez et al. 2002, Comisión Nacional de Áreas Naturales Protegidas 2007). In this area there are also reports of other wild felids such as puma (Puma concolor), bobcat (Lynx rufus), ocelot (Leopardus pardalis), and margay (Leopardus wiedii; Mendoza-Vega 2012, AguilarLópez and Ramos-Frías 2013).

We conducted our research from June to November 2013, using 3 methods: (i) cameratraps, (ii) tracks and scat, and (iii) interviews of forest rangers. For the first method we employed 11 camera-traps (2 Cuddeback Attack, De Pere, WI; 1 Primos Hunting Truth Cam, Flora, MS; 8 Stealth Cam, Grand Prairie, TX), which were placed in 13 localities along trails (La Manzana, Maguey Verde, Camposanto del Oro "Cerro Boludo," Durango, La Encarnación, Durango “El Olivo," Durango “El Nebrote," 1.2 km SE Maguey Verde, La Manzana "El Atajo," Pelillos "Barranca de Pelillos," La Majada, Durango "La Manguita," La Mesa de Camposanto del Oro) and canyons for periods that ranged from 3 days to 3 months for a total of 553 days per camera-trap. The distance between each camera-trap was between 1 and $4.4 \mathrm{~km}$. For tracks and scat, we conducted field observations during 6 months of the study. For the last method we interviewed 8 forest rangers from the Parque Nacional Los Mármoles about local fauna. Unstructured interviews were done at localities Durango, Tinaja de Durango, and La Manzana (Zimapán municipality), and we also used photographic images of each animal to prevent mistakes with different common names of these species in the region.

We documented 2 reliable records of jaguar in the state of Hidalgo, which corresponded to 2 tracks of adult jaguar and a photograph. The tracks were found on 22 July on a trail used by humans, located $4.1 \mathrm{~km} \mathrm{NE}$ from Maguey Blanco $\left(20^{\circ} 56^{\prime} 46^{\prime \prime} \mathrm{N}, 99^{\circ} 14^{\prime} 36.91^{\prime \prime} \mathrm{W}\right.$, 1961 masl; Fig. 2A). The tracks were identified using a field guide of Mexican mammals (Aranda 2012) and later corroborated by a specialist (Rosas-Rosas personal communication). The vegetation of this site was mainly composed of pine-oak forest (80\%) and shrubs (20\%). The photograph (Fig. 2B) was taken on 21 October at 4:46 on a rainy cloudy day at a rocky site $5 \mathrm{~km}$ NE of Maguey Blanco, Pacula $\left(20^{\circ} 56^{\prime} 58.79^{\prime \prime} \mathrm{N}, 9^{\circ} 14^{\prime} 14.71^{\prime \prime} \mathrm{W}, 1913\right.$ masl). At the same site 15 days before, a photographic record of Puma concolor was obtained. At this 
site, the dominant vegetation is composed of $60 \%$ oak forest and $40 \%$ shrubs, surrounded by pine-oak forest. The sites of these 2 new records are separated by approximately $900 \mathrm{~m}$. At both sites, evidence of white-tailed deer (Odocoileus virginianus) and collared peccary (Pecari tajacu) were observed (Mendoza-Vega 2012, Aguilar-López and Ramos-Frías 2013); both are important prey for large carnivores such as jaguar and puma (Seymour 1989). According to the authorities of PNLM, there are no records of livestock predation by jaguars or any other large felid in the region, which explains the existence of abundant prey for this felid, such as the nine-banded armadillo (Dasypus novemcinctus), white-nosed coati (Nasua narica), white-tailed deer, collared peccary, and Virginia opossum (Didelphis virginiana) reported for this region (AguilarLópez and Ramos-Frías 2013).

These new records of jaguar were found $1.7 \mathrm{~km}$ from a federal highway and near 4 human settlements: Durango, municipality of Zimapán (509 inhabitants); Adjuntas, municipality of Pacula (153 inhabitants); Tinaja Durango, municipality of Zimapán (100 inhabitants); and Maguey Blanco, municipality of Pacula (14 inhabitants; Instituto Nacional de Estadística y Geografía 2010). In this region, the presence of jaguar is unknown to people, probably due to its secretive habits or its lowdensity populations (Ortega-Huerta and Medley 1999, Sunquist and Sunquist 2002).

Pine-oak forests are considered uncommon environments for jaguar (Sanderson et al. 2002). However, in San Luis Potosí and the Sierra Nanchititla (state of México) in central México, the presence of jaguar in this type of vegetation has been described, including elevational range (Monroy-Vilchis et al. 2008, 2009, Villordo-Galván et al. 2010). These temperate environments could provide suitable habitat for this felid by offering camouflage, shelter, abundant prey, and protection of its litters (Monroy-Vilchis et al. 2009).

We document for the first time the presence of jaguar in the state of Hidalgo; the closest record is $53.5 \mathrm{~km} \mathrm{SW}$ of Xilitla, San Luis Potosí (Villordo-Galván et al. 2010). Our records reduce the distribution gap between known populations of jaguars in San Luis Potosí and northern Puebla. The records also highlight the importance of wildlife ecological corridors at Sierra Madre Oriental
(Dueñas-López 2013), where protected areas like PNLM could work as habitat patches that would benefit jaguar dispersion. With this record of jaguar, Hidalgo is the 11th state in México where 6 species of felids coexist (Leopardus wiedii, Leopardus pardalis, Lynx rufus, Panthera onca, Puma concolor, and Puma yagouaroundii; Ceballos and Oliva 2005, Villareal et al. 2005, Ramírez-Bravo 2010), as well as the state where jaguar and puma coexist at altitudes >1200 masl (Sunquist and Sunquist 2002, Monroy-Vilchis et al. 2009).

Recently, distribution of jaguar in México has been modeled (Griogione et al. 2009, Rodríguez-Soto et al. 2011, 2013) to identify priority areas for conservation. These models emphasize the need for jaguar habitat connectivity in México. The PNLM represents a potential corridor for the dispersion of jaguar, linking the populations throughout San Luis Potosí, Querétaro, Veracruz, and Puebla. However, detailed studies are necessary to estimate jaguar population size and evaluate conservation status in Hidalgo. Because the jaguar is considered an umbrella species and an indicator of the health of an ecosystem (Eisenberg 1980, Noss 1995, Lambeck 1997), its presence can be used to promote the protection of temperate ecosystems in northwestern Hidalgo, which may be used as ecological corridors between the known populations of this felid. In this context, it is also necessary to consider the importance of Sierra Madre Oriental as a priority area for the conservation of jaguar in México (Villordo-Galván et al. 2010).

We thank J.I. Ángeles Escudero, D. Cervantes and V.D. Vite Silva for helping with fieldwork. Facilities and logistical support were provided by the staff and ejido commissioner from Bienes Comunales La Encarnación. We thank O. Rosas-Rosas for corroborating the identity of the tracks. Helpful comments and support were provided by J.P. Castillo-Landero and D. Gómez-Durán. We also thank the administration of the Parque Nacional Los Mármoles and the Comisión Nacional de Áreas Naturales Protegidas for providing support. Financial support was provided by CONANP/ DR06/13/PN11/PROCODES/5430/13.

\section{Literature Cited}

Aguilar-López, M., and J. Ramos-Frías. 2013. Monitoreo de las poblaciones de mamíferos medianos en 
la localidad de San José del Oro "San Vicente" Zimapán, Hidalgo, México. Comisión Nacional de Áreas Naturales Protegidas, Programa para la Conservación y Desarrollo, Hidalgo, México, CONANP/ DR06/13/PN11/PROCODES/5430/13.

ARAnda, M. 1996. Distribution and abundance of the jaguar, Panthera onca (Carnivora: Felidae) in the state of Chiapas, Mexico. Acta Zoologica Mexicana (n.s.) $45-52$.

Aranda, M. 2012. Manual para el rastreo de mamíferos silvestres de México. Comisión Nacional para el Conocimiento y Uso de la Biodiversidad, Distrito Federal, México.

Brown, E.D., AND C.A. LóPEZ-GonZÁLEz. 2001. Borderland jaguars. University of Utah Press, Salt Lake City, UT.

Caso, A., C. Lopez-Gonzalez, E. Payan, E. EiziRIK, T. DE Oliveira, R. Leite-Pitman, M. Kelly, and C. ValderRAMA. 2008. Panthera onca. The IUCN Red List of Threatened Species. Version 2014.3. [Accessed 15 February 2015]. http://www.iucnredlist.org

Ceballos, G., C. Chávez, R. List, and H. Zarza, editors. 2007. Conservación y manejo del jaguar en México: estudios de caso y perspectivas. Comisión Nacional para el Conocimiento y Uso de la BiodiversidadAlianza World Wildlife Fund/Telcel-Universidad Nacional Autónoma de México, Distrito Federal, México.

Ceballos, G., and G. Oliva, coordinators. 2005. Los mamíferos silvestres de México. Comisión Nacional para el Conocimiento y Uso de la Biodiversidad y Fondo de Cultura Económica, Distrito Federal, México.

Chávez, C., M. Aranda, and G. Ceballos. 2005. Panthera onca (Linnaeus, 1758). Pages 367-370 in G. Ceballos and G. Oliva, coordinators, Los mamíferos silvestres de México. Comisión Nacional para el Conocimiento y Uso de la Biodiversidad y Fondo de Cultura Económica, Distrito Federal, México.

Coates-Estrada, R., and A. Estrada. 1986. Manual de identificación de campo de los mamíferos de la estación de biología "Los Tuxtlas." Universidad Nacional Autónoma de México, Instituto de Biología, Distrito Federal, México.

Comisión Nacional de Áreas Naturales Protegidas. 2007. Estudio previo justificativo para la modificación del decreto por el que se pretende recategorizar el Parque Nacional Los Mármoles como Área de Protección de Flora y Fauna. Comisión Nacional de Áreas Naturales Protegidas. Secretaria del Medio Ambiente y Recursos Naturales, Distrito Federal, México.

COMISIÓN NACIONAL PARA EL CONOCIMIENTO Y USO DE LA Biodiversidad. 1997. Provincias Biogeográficas de México. Escala 1:4 000000 Catálogo de metadatos geográficos. Comisión Nacional para el Conocimiento y Uso de la Biodiversidad, Distrito Federal, México.

DuEÑAs-LóPEZ, M. 2013. Identificación de corredores biológicos potenciales para el jaguar (Panthera onca) en Sierra Abra Tanchipa, San Luis Potosí y sus límites estatales. Master's thesis, Colegio de Postgraduados, Campus Montecillo, Texcoco, Estado de México, México.

EisenberG, J.F. 1980. The density and biomass of tropical mammals. Pages 35-55 in M.E. Soulé and B.A. Wilcox, editors, Conservation biology: an evolutionaryecological perspective. Sinauer Associates, Sunderland, MA.
Griogione, M.M., K. Menke, C. López-González, R. List, A. Banda, J. Carrera, R. Carrera, A.J. Giordano, J. Morrison, M. Sternberg, Et AL. 2009. Identifiying potential conservation areas for felids in the USA and Mexico: integrating reliable knowledge across an international border. Oryx 43:78-86.

Instituto Nacional DE Estadística y Geografía. 2010. Censo de Población y Vivienda 2010. Resultados por localidad (ITER). Consultada el 10 de marzo de 2014. Distrito Federal, México.

LAMBECK, R.J. 1997. Focal species: a multi-species umbrella for nature conservation. Conservation Biology 11: 849-856.

Medellín, R.A., C. Equihua, C. Chetkiewicz, A. RabiNOWITZ, K.H. REDFORD, J.G. RoBINSON, E. SANDERSON, AND A. TABER, EDITORS. 2002. El jaguar en el Nuevo Milenio. Fondo de Cultura Económica, Universidad Nacional Autónoma de México, Wildlife Conservation Society, Distrito Federal, México.

Mejenes-López, S. DE M.A., M. Hernández-Bautista, J. Barragan-Torres, and J. Pacheco-Rodríguez. 2010. Los mamíferos en el estado de Hidalgo, México. Therya 1:161-188. dx.doi.org/10.12933/therya-10-19

Mendoza-Vega, L.A. 2012. Mamíferos del Parque Nacional Los Mármoles. Bachelor’s thesis, Universidad Autónoma del Estado de Hidalgo, Pachuca, México.

Monroy-Vilchis, O., C. Rodríguez-Soto, M. ZarcoGonZÁlez, AND V. URIOS. 2009. Cougar and jaguar habitat use and activity patterns in central Mexico. Animal Biology 59:145-157.

Monroy-Vilchis, O., O. SÁnchez, U. Aguilera-Reyes, P. SuÁREZ, AND V. URIos. 2008. Jaguar (Panthera onca) in the state of Mexico. Southwestern Naturalist 53: 533-537.

Noss, R.F. 1995. Maintaining ecological integrity in representative reserve networks. World Wildlife Fund, Toronto, Ontario/Washington, DC.

Nowell, K., AND P. JACKSON. 1996. Wild cats: status survey and conservation action plan. IUCN/SSC Cat Specialist Group, Gland, Switzerland.

Ortega-Huerta, M.A., and K.E. Medley. 1999. Landscape analysis of jaguar (Panthera onca) habitat using sighting records in the Sierra de Tamaulipas, Mexico. Enviromental Conservation 26:257-269.

Ortega-Urrieta, A. 2005. Distribución y uso de hábitat del jaguar (Panthera onca) y el puma (Puma concolor) en la Reserva de la biosfera Sierra Gorda, Querétaro, México. Master's thesis, Universidad Autónoma de Querétaro, Querétaro, México.

Rabinowitz, A., And K.A. Zeller. 2010. A range-wide model of landscape connectivity and conservation for the jaguar, Panthera onca. Biological Conservation 143:939-945.

Ramírez-Bravo, O.E. 2007. Desarrollo de un modelo predictivo para la determinación de viabilidad de hábitat a 200 años para poblaciones de jaguar (Panthera onca) en la Sierra Madre Oriental. Master's thesis, Universidad Autónoma de Querétaro, Querétaro, México.

Ramírez-Bravo, O.E. 2010. El jaguar en Puebla: presencia, distribución, relación con el hombre y conservación. 2 reporte anual. Universidad de las Américas, University of Kent, National Geographic, Durrell Wildlife Conservation Trust, Panthera, Consejo Nacional de Ciencia y Tecnología, Reserva de la Biosfera de “Tehuacán-Cuicatlán,” Área de Protección de Recursos 
Naturales "Cuenca Hidrográfica del Río Necaxa," Puebla, México.

Rodríguez-Soto, C., O. Monroy-Vilchis, L. Maiorano, L. Boitani, J.C. Faller, M.A. Briones, R. Nuñez, O. Rosas-Rosas, G. Ceballos, and A. Falcucci. 2011. Predicting potential distribution of the jaguar (Panthera onca) in Mexico: identification of priority areas for conservation. Diversity and Distributions $17: 350-361$.

Rodríguez-Soto, C., O. Monroy-Vilchis, and M.M. ZarCo-GonZÁLEZ. 2013. Corridors for jaguar (Panthera onca) in Mexico: conservation strategies. Journal for Nature Conservation 21:438-443.

Rosas-Rosas, O.C., and J.H. López-Soto. 2002. Distribución y estado de conservación del jaguar en Nuevo León, México. Pages 393-402 in R.A. Medellín, C. Equihua, C. Chetkiewicz, A. Rabinowitz, K.H. Redford, J.G. Robinson, E. Sanderson, and A. Taber, editors, El jaguar en el Nuevo Milenio. Fondo de Cultura Económica, Universidad Nacional Autónoma de México, Wildlife Conservation Society, Distrito Federal, México.

Ruíz, G., P. Oropeza, J. Bernal, F. Durand, and O. RAMíREz. 2006. Vigilancia participativa: organización e instrumentación. Pages 51-56 in C. Chávez and G. Ceballos, editors, El jaguar mexicano en el siglo XXI: situación actual y manejo. Comisión Nacional para el Conocimiento y Uso de la BiodiversidadAlianza World Wildlife Fund/Telcel-Universidad Nacional Autónoma de México, Distrito Federal, México.

Sanderson, E.W., K.H. Redford, C. Chetkiewicz, R. Medellin, A.R. Rabinowitz, J.G. Robinson, And A. TABER. 2002. Planning to save a species: the jaguar as a model. Conservation Biology 16:58-72.

Secretaría de Agricultura y Recursos Hidráulicos. 1994. Diagnóstico del Parque Nacional Los Mármoles. Subsecretaría Forestal y de Fauna Silvestre, Consultores en Ecología y Medio Ambiente, Hidalgo, México.

Secretaría del Medio Ambiente y Recursos NatuRALES. 2010. Norma oficial mexicana NOM-059SEMARNAT-2010, protección ambiental-especies nativas de México de flora y fauna silvestres-categorías de riesgo y especificaciones para su inclusión, exclusión o cambio-lis de especies en riesgo. Segunda sección. Secretaría de Medio Ambiente y Recursos Naturales, Diario Oficial, 30 diciembre 2010, México, Distrito Federal, México.

Seymour, K.L. 1989. Panthera onca. Mammalian Species 340:1-9.

Sunquist, M., And F. Sunquist. 2002. Wild cats of the world. University of Chicago Press, London, United Kingdom.

Telléz-Girón, G., And W. López-Forment. 1995. Panthera onca veraecrucis (Carnivora: Felidae) en Querétaro, México. Revista Mexicana de Mastozoología 1:73-75.

Tewes, M., AND D. SchmidLy. 1987. The Neotropical felids: jaguar, ocelot, margay, and jaguarondi. Pages 697-712 in J.A. Novak, M.E. Baker, M.E. Obbard, and M. Malloch, editors, Wild furbearer management and conservation in North America. Ministry of Natural Resources, Ontario, Canada.

Velázquez, A., J.F. Mass, and J.L. Palacio. 2002. Análisis de cambio de uso de suelo. Instituto de Geografía, Universidad Nacional Autónoma de México, Instituto Nacional de Ecología, Secretaría de Medio Ambiente y Recursos Naturales, Distrito Federal, México.

Villareal, O.A., R. Guevara, R. Reséndiz, J.S. HernándeZ, J.C. Castillo, and F.J. Tomé. 2005. Diversificación productiva en campo experimental Las Margaritas, Puebla, México. Archivos de Zootecnia 54:197-203.

Villordo-Galván, J.A., O.C. Rosas-Rosas, F. ClementeSánchez, J.F. Martínez-Montoya, L.A. TarangoArámbula, G. Medoza-Martínez, M.D. SánchezHermosillo, and L.C. Bender. 2010. The jaguar (Panthera onca) in San Luis Potosí, México. Southwestern Naturalist 55:394-402.

Zanin, M., F. Palomares, and D. Brito. 2015. The jaguar's patches: viability of jaguar populations in fragmented landscapes. Journal for Nature Conservation 23:90-97.

Received 27 July 2014

Accepted 9 September 2015 